\title{
Advanced B-Cell Neoplasm
}

National Cancer Institute

\section{Source}

National Cancer Institute. Advanced B-Cell Neoplasm. NCI Thesaurus. Code C148065.

A mature B-cell neoplasm or B lymphoblastic leukemia/lymphoma that has spread

extensively to other anatomical sites or is no longer responding to treatment. 